\title{
The Labour Market Value of Liberal Arts and Applied Education Programs: Evidence from British Columbia
}

\author{
Maria Adamuti-Trache \\ University of British Columbia \\ Colleen Hawkey \\ British Columbia Teachers' Federation \\ Hans G. Schuetze \\ University of British Columbia \\ Victor Glickman \\ University of British Columbia
}

\begin{abstract}
In this article, labour market outcomes of British Columbia graduates from liberal arts and applied education programs are investigated by examining the 1996 cohort of baccalaureate graduates one year and five years after graduation. We argue that the individual return to education has to be analyzed from a multi-dimensional perspective, in relation to initial educational and career goals of graduates who have anticipated both intellectual challenges and economic rewards from their investment in education. The study reveals differences in outcomes (i.e., employment, earnings) by program type, gender and age. Our main conclusion is that graduates from applied education programs experience a more rapid integration into the labour market as compared to graduates from liberal arts education programs. Although earning differences by program type and age either decrease or even disappear over time, earning differences by gender are enhanced five years after graduation. Also, we conclude that graduates from applied education programs establish and accomplish more focused educational and career goals, while graduates from liberal education programs establish broader educational and career goals.
\end{abstract}




\section{RÉSUMÉ}

On examinera les débouchés sur le marché de travail qui s'ouvrent aux jeunes issus des études post-secondaires professionnelles ou généralistes, à l'aide des données sur la cohorte de bacheliers de 1996, obtenues un an et cinq après la fin de leurs études. Nous affirmons que le retour individuel vers l'éducation doit être examiné dans une perspective multidimensionnelle, en rapport avec les buts éducationnels et la carrière des bacheliers, qui ont anticipé à la fois des difficultés intellectuelles et des récompenses financières de leur investissement dans le processus d'éducation. L'analyse montre des différences au niveau des débouchés (par exemple emploi, salaire), en fonction du type de programme scolaire suivi, de l'âge et du sexe. Notre conclusion principale est que les jeunes qui ont poursuivi des études professionnelles s'adaptent plus rapidement aux demandes du marché du travail que ceux issus des études généralistes. Alors que la relation de dépendance entre les différences de salaire et le type d'étude ou l'âge diminue, voire disparaît avec le temps, la relation de dépendance entre différences des salaires et sexe augmente cinq ans après la fin des études. On conclut aussi que les jeunes ayant poursuivi des études professionnelles envisagent et réalisent des buts éducationnels et de carrière plus précis, alors que ceux qui ont fini des études généralistes envisagent des buts éducationnels et de carrière plus larges.

As shown in the report Education in Canada: Raising the standard (Statistics Canada, 2003a), Canada has become a world leader in education. "Indeed, the 2001 Census marked the first time that a majority of the working-age population had post-secondary credentials" (p.10), and 23\% of the active population were university degree holders. Over the last decade, the number of post-secondary graduates increased by 51\% at the university level, $48 \%$ at the community college level, while growth in trades was only $13 \%$. The proportion of university graduates among women aged 25 and over has grown from 14\% in 1991 to $20 \%$ in 2001. Also, 2001 Census data show that among working-age university graduates, the largest proportion obtained degrees in education, engineering, business and commerce, and financial management. The orientation toward specific fields of study is due to the increased demand for related occupations in the labour market and is reflected in more stable and well rewarded jobs.

Even though employment rates are high for all university graduates, there are differences by field of study. Analyses based on the National Graduates Survey of the 1990 cohort (Finnie, 2001) show that unemployment rates vary between 1\% for graduates (male and female) in Engineering to 6\% for graduates (male only) in Social Sciences or 8\% for graduates (female only) of Fine Arts and Humanities programs. Five years after graduation, average earnings vary by field of study and gender, from $\$ 88,900$ for Medical professions (male) to \$31,400 for Fine Arts and Humanities (female). Finnie notes that graduates from applied fields tend to perform better on objective measures of career success (e.g., 
employment and earnings) as compared to those in liberal arts fields. However, since their overall evaluation of academic program and job satisfaction are rated high by graduates from liberal arts fields, Finnie concludes that more than just objective measures of labour market outcomes determine why graduates embark on specific university programs.

Drawing on the field of study argument made by several authors, our study aims to discuss differences and similarities in labour market participation for liberal arts and applied education program graduates of the British Columbia Class of '96, one and five years after graduation. We argue that professional attainment and career success need to be analyzed from a broad perspective that includes not only the objective measures of graduates' outcomes in the labour market, but also graduates' views about their educational and career goals. Satisfaction with their university education, as compared to their educational goals and expected economic benefits, provides an individual perspective of how students approach their involvement in post-secondary education. Rather than providing a comprehensive analysis of graduates' labour market outcomes, this paper explores patterns of change in some relevant measures (e.g., employment status and earnings) and introduces an individual perspective to describing career attainment.

\section{REVIEW OF THE LITERATURE AND THEORETICAL FRAMEWORK}

If Canadians view university as the major institution for advanced preparation of the workforce, an optimal match between university education and the requirements of the labour market increases the employability, earnings, and job satisfaction of graduates and thus maximizes their rate of return to education. If there is indeed a good match, graduates become integrated rapidly into the labour market, perform well in their jobs, and make full use of knowledge and skills accumulated during their studies (Brown, 2001a, 2001b; Heijke \& Muysken, 2000). In this case, graduates have the feeling that educational goals and expectations have been reached, and their work situation can ensure full professional and social integration. As such, the efficacy of university programs fulfils both individual and societal needs.

Many analysts acknowledge that occupations relying mostly on technology and requiring specialized skills and competencies are highly valued in knowledge economies (Lavoie \& Roy, 1998) and are likely to be rewarding for individuals. However, Davenport (2002) draws attention to the fact that "Canadian companies are looking for graduates with the ability to communicate clearly both orally and verbally, work effectively in teams, think critically and creatively, solve problems, and exercise leadership" (p. 46). Graham (2002) points out that the notion of "wealth creation" grants the privilege of usefulness to applied activities, although "all serious intellectual inquiry can be declared valuable in terms of wealth-creation" (p. 29). This broader definition of wealth creation becomes even more valid in knowledge-based economies. Axelrod (2002) 
maintains that workers are expected now to be problem solvers in addition to possessing specific skills and competencies. He acknowledges that a marketdriven economy will continuously favour the development and expansion of vocational programs that can immediately respond to the demands of a global economy. However, the liberal education tradition that contributes to the wellrounded preparation of graduates should be enhanced through the development of stronger general education programs offered to all university students, since "the university must not be permitted to raze its own intellectual and cultural foundations" (Axelrod, Anisef, \& Lin, 2001, p. 76).

The transition from higher education to the labour market is a major challenge for graduates, post-secondary institutions, and the labour market itself. In the end, the success of this transition stage depends on the employability of graduates. Brown, Hesketh, and Williams (2003) view the employability of graduates from a dual perspective. Its absolute dimension refers to skills and knowledge that graduates possess and are able to utilize to meet employers' requirements. From a relative perspective, "our definition of employability has recognised that it is possible to be employable but not be in employment. This is intended to highlight the fact that graduate employability is primarily about the relative chances of finding and maintaining jobs as knowledge workers" (p. 122). The law of supply and demand for jobs within the labour market, the specificity of credentials possessed by graduates, as well as opportunities for further education, determine the patterns of employment and school participation among graduates. The authors show that the ability of graduates to capitalize on their credentials by obtaining a good "ranking" in the labour market has to be viewed in conjunction with the "rigging" of the market for credentials.

Pitcher and Purcell (1998) explored the graduate labour market by interviewing UK final year undergraduate students in various fields to determine what expectations graduates-to-be have about future employment. The authors found that more than one third of students, especially male students, were confident and willing to move directly into employment related to their longerterm careers. Authors note that this pragmatic tendency was higher among students from vocational programs. Meanwhile, those from liberal arts education programs anticipated temporary jobs, although higher proportions of these respondents were already enrolled in further studies at the graduate level as a means of raising their qualifications and increasing employability. Pragmatic attitudes toward employment were also manifested by mature students who seemed to have more instrumental employment-related reasons to complete university degrees. Maslove, Fischer, and O'Heron (1998) indicate that mature students may benefit from additional work experience accumulated before or during studies that leads to a more profitable use of their bachelor degrees.

Lin, Sweet, Anisef, and Schuetze (2000) suggest that transition success in the labour market is related to the type of university program. They analyze how employability skills possessed, acquired, and utilized are rated by graduates and 
to what extent they appear to be translated into better employment. Significant differences between the liberal arts and vocational education graduates are found only in terms of skills utilization. Lin, Sweet, and Anisef (2003) advanced two possible explanations: "workplace affords liberal graduates few opportunities to engage their skills" or "employers fail to make the best use of talents possessed by liberal graduates” (p. 73). Their findings suggest that possession of a university credential is not by itself a passport to stable and well-rewarded employment and the choice of field of study is risky. This study is in agreement with the theoretical framework developed by Brown et al. (2003) that describes graduate employability as a relative notion, which is shaped by concrete circumstances in the labour market. Yet, researchers need to explore more thoroughly the reasons why liberal education graduates are more vulnerable to labour market's fluctuations and for how long after university graduation they appear to hold less secure jobs than do graduates from applied programs.

In Canada, the National Graduate Surveys (NGS) conducted by Statistics Canada is an important database of labour market outcomes for several cohorts of post-secondary graduates. The existing follow-up surveys carried out two and five years after graduation are suited for longitudinal analysis. Comparisons of outcomes among cohorts also permit the analysis of results within the context of changing conditions in the labour market. Several educational studies addressing the topic of labour market outcomes, university accountability, and post-secondary graduates' profiles have been based on an analysis of NGS data (Allen, Harris, \& Butlin, 2003; Finnie, 2001; Lin et al., 2000; Lin et al., 2003). For instance, Allen et al. (2003) present a favourable profile of young Canadian graduates who went straight from high school to post-secondary education. The authors compare the labour market outcomes and transition to work for bachelor and community college graduates of the 1995 cohort to the outcomes of previous cohorts of graduates. They show that community college and especially university education pays off in long-term dividends leading to a better chance for non-university graduates to secure permanent employment, and for university graduates to find jobs matched to their level of education and receive better earnings. Finnie (2001) shows that unemployment rates of university graduates of the 1990 cohort decrease over time. Their jobs appear to follow quite stable patterns, with large proportions of full-time employment and good job-to-education matching.

However, the above studies show that there are differences in earnings by gender and field of study. Even if, in some fields, women's wages have shown dramatic increases over the years (Easton, 2002; Finnie, 2001), in all fields, women's earnings are behind those of their male colleagues. For both community college and university graduates, the best paid disciplines are engineering and applied sciences, while arts and humanities are situated at the lower end of the scale (Allen at el., 2003; Finnie, 2001). Research consistently shows that professional occupations that require applied education, like engineering, health, law, business and commerce, lead to higher incomes than 
most arts and science occupations based on a liberal education (Lin et al., 2000). Similarly, in a study of labour market outcomes comparing Canadian born with immigrants, Adamuti-Trache and Sweet (2005) demonstrate that "the negotiation of credentials in the labour market is significantly determined by origin of education, level of education and field of study. Earnings advantages are created for holders of graduate degrees in applied fields who obtained their education in Canada or an English-speaking country" (p.194).

This earnings difference fuels debate over the value and usefulness of applied (vocational) versus liberal traditions in education. Axelrod (2002) argues that "obtaining a job and earning a reasonable income is, of course, a significant part of this [labour market] experience. So, too, is being inquisitive, informed, and engaged in the life of the mind and of one's community" (p. 85). Individuals recognize that often intellectual rewards have compensatory effects in less financially rewarding occupations. However, from a societal, pragmatic perspective, large differences in income between fields can create an imbalance in the optimal production and utilization of human capital. The tendency among BC high school graduates to enrol in academic programs that can lead to high-income occupations is evident in the higher admission grade requirements for engineering, science, business and commerce programs, as compared to arts. Further, for science undergraduates, the competition for admission to medical school is higher than the competition for majors in the natural sciences. The existing situation of graduates' earnings in the labour market influences the young generation of university students who strive for the opportunity to train in those occupations that appear to be more secure and better rewarded financially.

\section{DATA COLLECTION AND RESEARCH DESIGN}

In addition to the National Graduate Surveys conducted by Statistics Canada, several provinces conduct their own graduate surveys. One example is the survey of baccalaureate graduates from British Columbia's public universities conducted by The University Presidents' Council of British Columbia (TUPC). Another example is the census survey of university graduates conducted every two years province-wide across Québec by Ministère de l'Éducation (2003).

The annual TUPC surveys of baccalaureate graduates of $\mathrm{BC}$ public universities allow for a comprehensive and accurate study of BC university graduates. Since 1995, follow-up surveys have been administered two and five years after graduation. These surveys contain information on post-secondary academic programs and completed degrees. Graduates answer questions about their educational and career aspirations and expectations, post-secondary educational attainment, as well as attitudes toward and beliefs about education and work. They express their level of satisfaction with the education received and comment on programs, course availability, and skills development. Also, graduates describe their current employment status, occupation and earnings, and the extent to which their education relates to job demands. 
As shown by earlier analyses on the BC University Baccalaureate Graduate Surveys (Hawkey \& Lee, 1999; Sudmant, Greenall, Lambert-Maberly, \& Dumaresq, 2003), most graduates regard their integration into the labour market as a gradual process, combining work with the search for better jobs while pursuing additional education. Field of study appears to be a significant factor in determining employment rates and salaries. Graduates from applied fields perform better in the labour market than those from liberal arts programs, although a comparison between the two-year and five-year follow-ups reveals an increase of earnings for all graduates.

The current paper entails the use of data from the 1997 and 2001 surveys of 1996 graduates of the three major public universities in British Columbia. ${ }^{1}$ The analysis covers baccalaureate graduates from The University of British Columbia, Simon Fraser University and University of Victoria who clearly indicated their program of study and type of degree. Since the University of Northern BC was only founded in the early 1990s, and had a small number of graduates in 1996 and a limited number of academic programs, it was omitted from this study. The fifth university in BC, Royal Roads University, was established in 1995 and did not have any graduates at the time of the surveys. In this paper, we look at outcomes of undergraduate university education distinguishing between liberal arts and applied programs. The study addresses the following research questions:

- What is the employment situation of graduates from liberal arts and applied programs one year and five years after graduation? How well does each group fare in the labour market in terms of employment and income? Are they enrolled in further education?

- How do liberal arts education graduates define their initial educational goals and university expectations in comparison to graduates of applied programs?

- Are there gender and age differences in graduates' labour market outcomes? Do these group differences change over time?

The three established universities offer a large number of academic programs, which are grouped in the TUPC database according to the Classification of Instructional Programs (CIP) coding scheme (Table 1). For the purpose of this study, academic programs are aggregated into liberal arts and applied programs following the work of Lin et al. (2000), which was done at the level of each individual academic program based on academic curriculum. ${ }^{2}$ Liberal arts programs are mostly arts and science, while applied programs include professional fields like education, engineering, health, law and business. This paper focuses on a longitudinal analysis of various measures of graduates' labour market outcomes, ${ }^{3}$ as well as graduates' views of university education as reflected by their educational goals and the reasons for enrolling in further education, reported one and five years after graduation. 


\section{Research sample}

The longitudinal research sample was obtained by merging data collected from two follow-up surveys (1997 and 2001). For each survey, attempts were made to reach all 8,613 graduates identified for surveying, with a response rate of 72\% in 1997 and 63\% in 2001 (Hawkey \& Lee, 1999; Sudmant et al., 2003). The longitudinal sample that includes only those who answered both surveys has 4,065 respondents, representing about 47\% of the 1996 graduates of the Class of '96. The 1997 and 2001 sample distributions by institution, gender, age, and type of program are very similar to the longitudinal sample, which indicates a stability of the demographic composition of samples over time.

As shown in Table 1, the sample has a larger proportion of women (62\%) than men (38\%), and an almost even distribution of graduates in liberal arts programs (51\%) and applied programs (49\%). Within the liberal arts programs, the largest group was enrolled in Social Sciences (47\%), followed by the Humanities

Table 1:

Distribution of research sample by type of program and gender

\begin{tabular}{|c|c|c|c|c|c|c|c|}
\hline \multirow[t]{2}{*}{ Type of Program ${ }^{a}$} & \multicolumn{2}{|l|}{ Program (CIP) } & \multicolumn{2}{|l|}{ Male } & \multicolumn{2}{|c|}{ Emale } & All \\
\hline & & $\mathrm{N}$ & $\%$ & $\mathrm{~N}$ & $\%$ & $\mathrm{~N}$ & $\%$ \\
\hline \multirow{6}{*}{$\begin{array}{l}\text { Liberal Arts } \\
\text { programs }\end{array}$} & Fine Arts & 39 & 5 & 100 & 8 & 139 & 7 \\
\hline & Social Sciences & 379 & 49 & 602 & 47 & 981 & 47 \\
\hline & Humanities & 102 & 13 & 369 & 29 & 471 & 23 \\
\hline & Life Sciences & 178 & 23 & 181 & 14 & 359 & 17 \\
\hline & Physical Sciences & 84 & 11 & 44 & 3 & 128 & 6 \\
\hline & Total & 782 & 100 & 1296 & 100 & 2078 & 100 \\
\hline \multirow{13}{*}{$\begin{array}{l}\text { Applied } \\
\text { programs }\end{array}$} & Computing Science & 71 & 9 & 15 & 1 & 86 & 4 \\
\hline & Engineering & 149 & 19 & 29 & 2 & 178 & 9 \\
\hline & Education & 187 & 24 & 543 & 45 & 730 & 37 \\
\hline & Law & 46 & 6 & 34 & 3 & 80 & 4 \\
\hline & Health Professions & 43 & 6 & 225 & 19 & 268 & 14 \\
\hline & Fitness, Kinesiology & 59 & 8 & 68 & 6 & 127 & 6 \\
\hline & Business & 157 & 20 & 124 & 10 & 281 & 14 \\
\hline & Natural Resources & 44 & 6 & 33 & 3 & 77 & 4 \\
\hline & Social Sciences ${ }^{b}$ & 12 & 2 & 99 & 8 & 111 & 6 \\
\hline & Humanities ${ }^{b}$ & 7 & 1 & 17 & 1 & 24 & 1 \\
\hline & Life Sciences ${ }^{b}$ & 5 & 1 & 20 & 2 & 25 & 1 \\
\hline & Total & 780 & 100 & 1207 & 100 & 1987 & 100 \\
\hline & Total research sample & 1562 & & 2503 & & 4065 & \\
\hline
\end{tabular}

${ }^{a}$ Classification by type of program follows the methodology of Lin et al. (2000)

${ }^{\mathrm{b}}$ See Note 2 . 
(23\%) and the Life Sciences (17\%), while fewer students were enrolled in Fine Arts (7\%) and Physical Sciences (6\%). There is an overrepresentation of men in Life and Physical Sciences (34\% men as compared to 17\% women), and of women in the Humanities (29\% women as compared to 13\% men). Within applied education programs, the largest group was enrolled in Education (37\%), followed by Business (14\%), Health (14\%) and Engineering (9\%), while the remaining fields enrolled about $26 \%$ graduates. There is an overrepresentation of men in Engineering (19\% men as compared to 2\% women) and Business (20\% men as compared to $10 \%$ women), while women are overrepresented in Education (45\% women as compared to 24\% men) and Health (19\% women as compared to $6 \%$ men).

Table 2 presents the sample distribution by gender and age at the time of graduation, for liberal arts and applied programs. The average age of the sample was approximately 28 due to the large proportion (56\%) of non-traditional graduates (25 years of age or older). It is also noticeable that the age patterns are largely different by type of program, with more traditional age students (less than 25 years old) in liberal arts programs (52\%) compared to applied programs (36\%). The age difference can be explained in part because applied programs such as law or education require the completion of a bachelor degree, or several years of undergraduate instruction prior to the professional program. Although it is problematic to equate longer programs with more education, one can expect that graduates of professional programs will benefit from better employment outcomes (Walters, 2004).

Table 2

Distribution of research sample by type of program, gender and age

\begin{tabular}{|c|c|c|c|c|c|c|c|c|c|c|c|c|}
\hline \multirow{3}{*}{ Age groups } & \multicolumn{6}{|c|}{ Liberal Arts programs } & \multicolumn{6}{|c|}{ Applied programs } \\
\hline & \multicolumn{2}{|c|}{ Male } & \multicolumn{2}{|c|}{ Female } & \multicolumn{2}{|c|}{ All } & \multicolumn{2}{|c|}{ Male } & \multicolumn{2}{|c|}{ Female } & \multicolumn{2}{|c|}{ All } \\
\hline & $\mathrm{N}$ & $\%$ & $\mathrm{~N}$ & $\%$ & $\mathrm{~N}$ & $\%$ & $\mathrm{~N}$ & $\%$ & $\mathrm{~N}$ & $\%$ & $\mathrm{~N}$ & $\%$ \\
\hline 24 or less & 392 & 50 & 695 & 54 & 1087 & 52 & 286 & 37 & 424 & 35 & 710 & 36 \\
\hline $25-29$ & 288 & 37 & 352 & 27 & 640 & 31 & 335 & 43 & 403 & 33 & 738 & 37 \\
\hline $30-39$ & 67 & 9 & 129 & 10 & 196 & 9 & 104 & 13 & 201 & 17 & 305 & 15 \\
\hline $40+$ & 35 & 5 & 120 & 9 & 155 & 8 & 55 & 7 & 179 & 15 & 234 & 12 \\
\hline Total & 782 & & 1296 & & 2078 & & 780 & & 1207 & & 1987 & \\
\hline
\end{tabular}

Within each type of program, the age distribution is different by gender, especially for older age groups. For the liberal arts programs, a slightly larger participation rate of women over 40 is noticeable. This is accentuated for the applied programs, in which 32\% of female graduates are over 30 years old and $15 \%$ of women are over 40 at the time of graduation. Higher university participation rates by women over 40 at the time of graduation may be explained 
by the fact that women are more likely to study part-time or return to study after having raised children, thereby taking longer to graduate (Andres \& Carpenter, 1997). In Table 2, the four age groups with at least 5\% representation were presented in order to draw attention to the age diversity of the student body. In the following analysis, the latter three groups are aggregated, and we will only distinguish between traditional (less than 25 years old at the time of graduation) and non-traditional ( 25 years of age or older) baccalaureate graduates.

\section{STUDY FINDINGS}

First, we present longitudinal findings on labour market outcomes (employment and earnings) by program type, gender, and age. In defining the current status of graduates, we consider both employment situation and participation in formal education. Next, we contrast educational goals and goal attainment as described one year after graduation by type of program and age. Finally, we compare graduates' views about continuing further education by type of program.

\section{Transition from School to Work and Continuing Studies over Time}

The survey data show complex patterns of employment and participation in further education. ${ }^{4}$ Graduates were employed full-time or part-time, or were not-employed, while continuing or not continuing various forms of study (hereafter referred to as 'school'). ${ }^{5}$ Graduates who gave clear answers regarding their employment and continuing education were included for this part of the analysis $(\mathrm{N}=3,990)$, and classified under six employment-school categories. In the Appendix, we present detailed distributions of graduates across employment and school status categories by type of program, age and gender in Table A1 (one year after graduation) and Table A2 (five years after graduation). Elements of these two tables will be used to demonstrate differences in employment and school status by type of program (Table 3), gender (Table 4), and age (Table 5) at both survey times and to compare changes over the years.

Employment status by type of program. As Table 3 shows, larger proportions of graduates from applied programs (over 90\%) compared to liberal arts programs (76\% in 1997 and 84\% in 2001) were employed. The proportion of graduates continuing their education (either while employed or not-employed) was $42 \%$ for liberal arts graduates and only 17\% for graduates from applied programs in 1997, indicating that the former sought additional qualifications beyond their first degrees. Meanwhile, more graduates from applied programs (80\% versus 53\% from liberal arts programs) were employed, full-time or parttime, and not enrolled in formal education in 1997.

These differences are attenuated in 2001, when the number of graduates from applied programs enrolled in various forms of further education increased (from 17\% to 25\%) and the proportion of those employed and not in school decreased from $80 \%$ to $69 \%$. By comparison, the proportion of liberal arts 
graduates employed and not in school increased from 53\% to 59\%. Whereas graduates from applied programs participated in the labour market sooner but returned in greater numbers to further education within five years after graduation, liberal arts graduates continued their education for longer periods of time and integrated later into the labour market. This is consistent with Giles (2002) who demonstrated that even if holders of liberal arts degrees have more difficulty with school-to-work transition in terms of employment, skills they accumulated have a "greater longevity" (p. 25).

Table 3

Employment status and participation in further education by type of program

\begin{tabular}{|c|c|c|c|c|c|c|c|c|c|c|c|c|}
\hline \multirow{3}{*}{$\begin{array}{l}\text { Employment and education } \\
\text { categories }\end{array}$} & \multicolumn{6}{|c|}{ One year after graduation } & \multicolumn{6}{|c|}{ Five years after graduation } \\
\hline & \multicolumn{2}{|c|}{$\begin{array}{l}\text { Liberal } \\
\text { Arts }\end{array}$} & \multicolumn{2}{|c|}{ Applied } & \multicolumn{2}{|c|}{ All } & \multicolumn{2}{|c|}{$\begin{array}{l}\text { Liberal } \\
\text { Arts }\end{array}$} & \multicolumn{2}{|c|}{ Applied } & \multicolumn{2}{|l|}{ All } \\
\hline & $\mathrm{N}$ & $\%$ & $\mathrm{~N}$ & $\%$ & $\mathrm{~N}$ & $\%$ & $\mathrm{~N}$ & $\%$ & $\mathrm{~N}$ & $\%$ & $\mathrm{~N}$ & $\%$ \\
\hline FT employed \& No School & 803 & 40 & 1181 & 60 & 1984 & 50 & 1043 & 51 & 1211 & 61 & 2254 & 56 \\
\hline PT employed \& No School & 258 & 13 & 381 & 20 & 639 & 16 & 167 & 8 & 147 & 8 & 314 & 8 \\
\hline FT employed \& School & 220 & 11 & 150 & 8 & 370 & 9 & 380 & 19 & 376 & 19 & 756 & 19 \\
\hline PT employed \& School & 273 & 13 & 101 & 5 & 374 & 9 & 129 & 6 & 50 & 3 & 179 & 4 \\
\hline Not-employed \& School & 366 & 18 & 81 & 4 & 447 & 11 & 177 & 9 & 56 & 3 & 233 & 6 \\
\hline Not-employed \& No School & 115 & 6 & 61 & 3 & 176 & 4 & 139 & 7 & 115 & 6 & 254 & 6 \\
\hline Total & 2035 & 100 & 1955 & 100 & 3990 & 100 & 2035 & 100 & 1955 & 100 & 39901 & 100 \\
\hline
\end{tabular}

There are noteworthy differences among graduates who were not in the labour market and were not going to school (the not-employed groups). In this category, the proportion of liberal arts graduates remained steady (6\% in 1997 and $7 \%$ in 2001), while the proportion of graduates from applied programs increased from 3\% in 1997 to 6\% in 2001. For the latter group, the increase was due to female respondents 25 years of age or older at the time of graduation. Over 60\% of not-employed women in this age group reported they were not in the labour market for family reasons (maternity leave, caring for children, family obligations). Therefore, the large proportions of graduates not-employed and not in school do not correspond to involuntary unemployment rates. In 2001, the unemployment rate (due to layoffs, losing or quitting a job, not finding a job) was about 3\% for liberal arts graduates and 2\% for applied programs graduates.

Gender differences in employment. Although women and men had comparable rates of employment, men were more likely than women to hold full-time jobs (Table 4). In 1997, 66\% of men and 55\% of women had full-time job, while in 2001, 82\% of men and 72\% of women were employed in full-time positions. At both survey times, there were insignificant gender differences in the group continuing with formal education or in the not employed group. Survey responses showed that while non-participation by women in the labour 
market was mostly explained by family obligations, larger proportions of men (over 50\%) than women (about 20\%) did not work in 2001 due to layoffs, losing, or quitting a job or not finding a job.

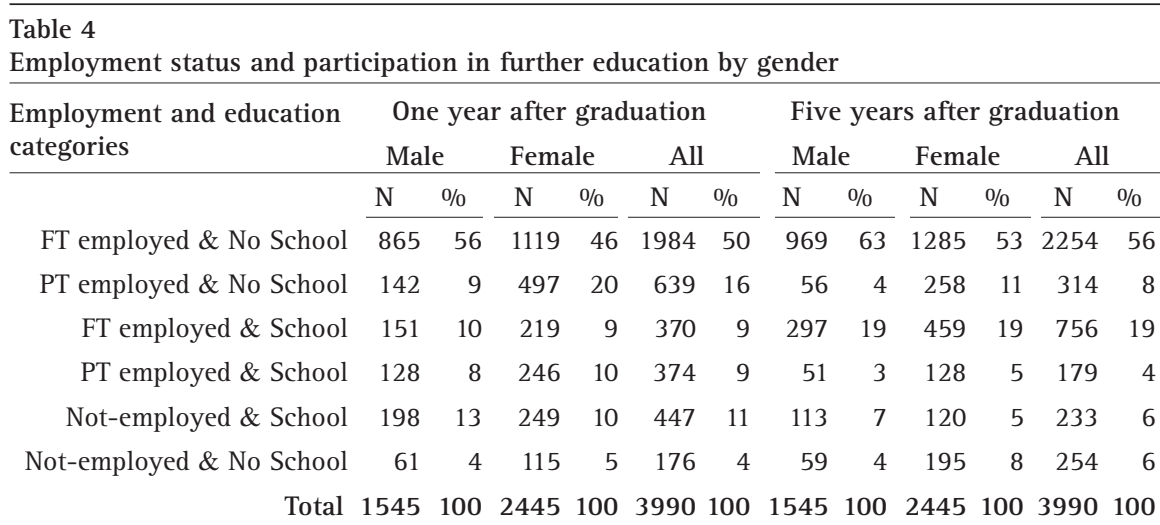

Age differences in employment. Since there is a noticeable relationship between age of respondents and the type of program from which they graduate (i.e., 53\% of graduates in liberal arts programs were under 25 years of age, only $36 \%$ of graduates from applied programs were in this group), age differences in employment-school status follow the patterns of differences by program type. As a result, the younger group showed a delayed but growing integration in the labour market and large participation in further education that decreased over time. The older group showed immediate integration in the labour market and steady and slight increase in participation in further education.

Giles (2002) used the Survey of Labour and Income Dynamics to analyze the duration of unemployment for university graduates in liberal arts and applied programs. He found that young graduates in the humanities and social sciences had a more "difficult transition into the labour market than their applied programs counterparts" (p.22). There are differences between Giles's classification of programs and the one used in our study: we include education among applied programs but keep biological and physical sciences among liberal arts programs. Regardless, our data also show that age combined with type of program make the younger graduates in liberal arts programs appear less integrated into the labour market, essentially due to the fact that large proportions of liberal arts graduates continue their studies. However, our longitudinal data allow us to determine whether age differences are maintained over time.

Table 5 shows that one year after graduation, the younger group was slightly less likely to be employed in a full-time job (57\%) compared to the older group $(61 \%)$. This situation was reversed five years after graduation, when $77 \%$ of the younger respondents as compared to $74 \%$ of the older respondents held full-time 
jobs. Overall, the proportion of the not-employed group was constant over time for the older group (12\%), while decreasing from 20\% to 13\% for the younger group. Proportions of those attending school were not very different over time: in 1997, about 38\% of the younger graduates as compared to $25 \%$ of the older graduates were involved in some type of continuing education. In 2001, the younger group decreased its school participation to 34\% while the older group continued education in an unchanged proportion of $25 \%$. It is interesting to note the large proportion (17\%) of the older respondents who continued their education while holding full-time jobs. Overall, five years after graduation, differences by age in the three categories (employment, not-employment and school participation) were diminished.

Table 5

Employment status and participation in further education by age groups

\begin{tabular}{|c|c|c|c|c|c|c|c|c|c|c|c|c|}
\hline \multirow{3}{*}{$\begin{array}{l}\text { Employment and } \\
\text { education categories }\end{array}$} & \multicolumn{6}{|c|}{ One year after graduation } & \multicolumn{6}{|c|}{ Five years after graduation } \\
\hline & \multicolumn{2}{|c|}{ Age $<25$} & \multicolumn{2}{|c|}{ Age $>25$} & \multicolumn{2}{|c|}{ All } & \multicolumn{2}{|c|}{ Age $<25$} & \multicolumn{2}{|c|}{ Age $>25$} & \multicolumn{2}{|c|}{ All } \\
\hline & $\mathrm{N}$ & $\%$ & $\mathrm{~N}$ & $\%$ & $\mathrm{~N}$ & $\%$ & $\mathrm{~N}$ & $\%$ & $\mathrm{~N}$ & $\%$ & $\mathrm{~N}$ & $\%$ \\
\hline FT employed \& No School & 808 & 46 & 1176 & 53 & 1984 & 50 & 985 & 56 & 1269 & 57 & 2254 & 56 \\
\hline PT employed \& No School & 214 & 12 & 425 & 19 & 639 & 16 & 103 & 6 & 211 & 10 & 314 & 8 \\
\hline FT employed \& School & 195 & 11 & 175 & 8 & 370 & 9 & 371 & 21 & 385 & 17 & 756 & 19 \\
\hline PT employed \& School & 202 & 11 & 172 & 10 & 374 & 9 & 92 & 5 & 87 & 4 & 179 & 4 \\
\hline Not-employed \& School & 281 & 16 & 166 & 7 & 447 & 11 & 138 & 8 & 95 & 4 & 233 & 6 \\
\hline Not-employed \& No School & 74 & 4 & 102 & 5 & 176 & 4 & 85 & 5 & 169 & 8 & 254 & 6 \\
\hline Total & 1545 & 100 & 2445 & 1003 & 3990 & 1001 & 1545 & 1002 & 2445 & 100 & 3990 & 100 \\
\hline
\end{tabular}

Earnings. To compare median incomes over time, we consider only respondents who worked full-time and were not participating in further education. The 1997 reported total income was converted to 2001 dollars. As reported in Table 6, graduates increased their median earnings by more than $23 \%$ over five years, which suggests that more graduates moved into better paying jobs as a result of increased credentials or experience.

There are significant income differences among age and gender groups at each moment in time. For instance, one year after graduation, older graduates obtained significantly higher incomes than younger graduates, namely 17\% and 6\% for the liberal arts and applied programs graduates, respectively. Five years after graduation, this difference was only about $2 \%$ for liberal arts programs graduates, and was reversed for graduates of applied programs with younger graduates earning more. We can conclude that age is not the most relevant factor regarding income: five years after graduation, median income of all graduates working full-time and not attending formal studies is very homogeneous across age groups.

Gender differences are visible in a number of areas. One year after graduation, men earned more than women: these differences were as large as $14 \%$ for the graduates from applied programs for those less than 25 years of 
Table 6

Median income by type program, age and gender over time (2001 BC dollars)

\begin{tabular}{|c|c|c|c|c|c|c|c|}
\hline \multirow{3}{*}{ Type of program } & \multicolumn{3}{|c|}{ One year after graduation } & \multicolumn{4}{|c|}{ Five years after graduation } \\
\hline & Age $<25$ & \multicolumn{2}{|c|}{ Age $>25$} & \multicolumn{2}{|c|}{ Age $<25$} & \multicolumn{2}{|c|}{ Age $>25$} \\
\hline & Male Female & Male & Female & Male & Female & Male & Female \\
\hline \multicolumn{8}{|l|}{ Liberal Arts programs } \\
\hline Time ${ }^{*}$ Age ${ }^{*}$ Gender & $31,500 \quad 31,500$ & 37,800 & 35,700 & 47,000 & 41,700 & 46,000 & 42,700 \\
\hline Time*Age & 31,500 & 36,8 & 300 & 43, & 000 & & 000 \\
\hline Time & \multicolumn{3}{|c|}{33,600} & \multicolumn{4}{|c|}{43,200} \\
\hline \multicolumn{8}{|l|}{ Applied programs } \\
\hline Time*Age ${ }^{*}$ Gender & $42,000 \quad 36,800$ & 42,000 & 38,900 & 60,000 & 45,000 & 55,000 & 47,000 \\
\hline Time*Age & 37,800 & 39,9 & 900 & 51, & 500 & 50 , & 000 \\
\hline Time & \multicolumn{3}{|c|}{39,900} & \multicolumn{4}{|c|}{50,000} \\
\hline All programs & \multicolumn{3}{|c|}{37,800} & \multicolumn{4}{|c|}{46,700} \\
\hline
\end{tabular}

age, while female and male liberal arts graduates, irrespective of age, had more comparable incomes. Five years after graduation, gender differences in median income became even more pronounced across all program types and age groups, and were as high as $8 \%$ and 13\% for the older and younger liberal arts graduates, respectively, and up to 17\% and 33\% for the older and younger graduates from applied programs, respectively. We conclude that gender remains a systemic factor differentiating respondents' median income over time. Our findings are in agreement with Finnie's study (2001) that shows that gender earnings gap is likely to grow over time.

\section{Educational Goals and Further Education}

In the previous section we presented the profiles of British Columbia university graduates of the Class of ' 96 from a labour market perspective. As shown, the type of program from which respondents graduated, combined with age and gender, have large impacts on their employment status, participation in further education, non-employment rates, and earnings.

The question we address in this section is whether differences observed in the labour market between graduates from liberal arts and applied programs are a reflection of individual attitudes toward education and work. Two measures are available for analysis. One year after graduation, graduates indicated their initial educational goals when they started the baccalaureate degree and the extent to which their goals were attained. Five years after graduation, graduates reported the reason to be enrolled at that time in further education and where did they enrol.

Educational goals in 1997. Multiple answers were recoded into three major goal groups: job-oriented goals (getting a better job, acquiring job skills), general goals (obtaining a baccalaureate degree, qualifying for a graduate program, broadening knowledge), less defined goals (pleasing parents/family, having no 
explicit personal goal). Since the focus of this study is to find how well graduates are prepared to succeed in the labour market, when multiple answers occurred (about 25\% of the sample), priority was given to the job-oriented goals.

Table 7 shows the distribution of initial educational goals and level of goals attainment as reported in 1997 by program type and age. Gender differences are less significant and are not presented. As expected, graduates of applied programs had more job-oriented goals (70\%) when deciding to pursue university education as compared to liberal arts graduates (50\%) who expressed a higher interest in broadening knowledge in a specific field. Not unexpectedly, students wanted to acquire skills that would lead to employment and more than two thirds of all graduates felt they attained their goals. About 13\% and 8\% of liberal arts graduates and graduates from applied programs, respectively, had no clear goals about university education. A large proportion of graduates from applied programs (79\%) felt that their goals had been completely or mostly attained, while only $63 \%$ of liberal arts graduates felt the same. There are no significant age differences in setting educational goals, although older graduates had more job-oriented goals. Only 66\% of the younger graduates felt they attained their goals in comparison to $75 \%$ of the older graduates.

Table 7

Initial educational goals \& goals attainment one year after graduation

\begin{tabular}{|c|c|c|c|c|c|c|}
\hline & \multicolumn{3}{|c|}{ Liberal Arts programs } & \multicolumn{3}{|c|}{ Applied programs } \\
\hline & Age $<25$ & Age $>25$ & All & Age $<25$ & Age $>25$ & All \\
\hline & $\%$ & $\%$ & $\%$ & $\%$ & $\%$ & $\%$ \\
\hline Job oriented goals & 50 & 51 & 50 & 65 & 72 & 70 \\
\hline General goals & 36 & 38 & 37 & 27 & 21 & 23 \\
\hline Less defined goals & 14 & 11 & 13 & 9 & 7 & 8 \\
\hline $\begin{array}{l}\text { Goals attainment } \\
\text { (mostly or completely) }\end{array}$ & 60 & 65 & 63 & 73 & 82 & 79 \\
\hline
\end{tabular}

Reasons to participate in formal education within five years after graduation. The employment and school profiles presented in Table 3 suggest that for large numbers of respondents formal education continued after completing undergraduate university education. Overall, about 30\% of all respondents in the sample indicated they enrolled in some form of education one year after graduation, and about $29 \%$ were enrolled in further education five years after graduation. Increased participation in further education between 1997 and 2001 was observed for graduates from applied programs. Five years after receiving a baccalaureate degree, about $25 \%$ of these graduates continued with some form of further education, this rate increasing from 17\% in 1997. The reverse phenomenon was observed for the liberal arts programs graduates; the proportion enrolled in formal education was larger in 1997 (almost 42\%) and decreased to $34 \%$ four years later. 
Where and why were respondents enrolled in further education? Within five years after graduating with a baccalaureate degree, almost $90 \%$ of graduates took some additional education or training. About 10\% of graduates indicated more than one form of education or training, but for the purpose of this paper we analyzed only the main response and only by type of program.

Table 8 shows that, for both groups, but especially for the applied programs graduates, the most frequently identified reason to continue education and training was career and employment related. Other reasons were to continue to further degree studies, and to experience intellectual challenges. Pursuing a new bachelor degree appeared to be a reason for liberal arts graduates, who were also substantially enrolled in graduate studies.

Respondents were most likely to engage in further education at the university level (49\%), with the largest enrolment coming from liberal arts programs graduates. As shown in Table 8, community colleges and other public post-secondary institutions were a second preferred option (or perhaps sole opportunity) for liberal arts graduates (20\% versus 14\% for applied programs), while graduates from applied programs also enrolled in training offered by employer, professional associations and private training institutions $(42 \%$ versus $17 \%$ for liberal arts programs).

Table 8

Further education and training (five years after graduation)

\begin{tabular}{|c|c|c|c|c|}
\hline \multirow[t]{2}{*}{$\begin{array}{l}\text { Main reason to enrol in } \\
\text { further education and where? }\end{array}$} & \multicolumn{2}{|c|}{$\begin{array}{l}\text { Liberal Arts } \\
\text { programs }\end{array}$} & \multicolumn{2}{|c|}{ Applied programs } \\
\hline & $\mathrm{N}$ & $\%$ & $\mathrm{~N}$ & $\%$ \\
\hline \multicolumn{5}{|c|}{ Reason } \\
\hline Pursue another Bachelor degree & 173 & 9 & 57 & 3 \\
\hline Pursue Masters studies & 218 & 12 & 181 & 10 \\
\hline Pursue Doctoral studies & 77 & 4 & 18 & 1 \\
\hline Career/job/employment related & 1103 & 58 & 1149 & 65 \\
\hline Challenge myself intellectually & 153 & 8 & 162 & 9 \\
\hline Required by employer & 41 & 2 & 66 & 4 \\
\hline Other & 120 & 6 & 115 & 7 \\
\hline \multicolumn{5}{|c|}{ Where } \\
\hline University & 1117 & 59 & 669 & 38 \\
\hline College, university college, institutes & 384 & 20 & 253 & 14 \\
\hline Private institutions & 119 & 6 & 157 & 9 \\
\hline Professional associations & 91 & 5 & 245 & 14 \\
\hline Employer & 107 & 6 & 333 & 19 \\
\hline
\end{tabular}




\section{DISCUSSION}

There is a net change in the labour market outcomes (i.e., employment status and earnings) of baccalaureate graduates of the Class of '96 over the years, with large differences by the type of program, and less influence of age and gender. About one third of graduates continued to be involved in formal education at both survey times, a result that supports previous findings that job demands become more dynamic in the knowledge-based economy and require frequent updating, adaptation, and continual learning (Rubenson \& Schuetze, 2000; Schuetze, 2000).

There were larger proportions of graduates from applied programs who were employed and not in school at both survey times. This gap decreased over time since liberal arts graduates, who continued studies since 1996 in large proportion, finished their education, while a large number of graduates from applied programs pursued further education after 1996. The unemployment rate in 2001 (layoffs, losing or quitting jobs, not finding jobs) was about 3\% for liberal arts graduates and $2 \%$ for graduates from applied programs. These rates are slightly below the British Columbia rate of unemployment for university graduates (4\%) in 2000 (Statistics Canada, 2003b).

Men are more likely than women to hold full-time instead of part-time jobs at both survey times, and this finding is in agreement with Finnie's analysis (2001) of the NGS 1990 cohort. While female graduates from the 1990 cohort show a steady rate of part-time employment over time, in the case of the BC Class of '96, the rate of part-time employment among women is clearly decreasing and follows similar patterns to that of their male counterparts.

The distribution of graduates by age groups matches their distribution by type of program, since most young respondents were holders of liberal arts degrees (53\%) rather than applied degrees (36\%). Consequently, the proportion of full-time employed who did not participate in further studies was visibly higher for older graduates as compared to young graduates. Young graduates were also more likely to be unemployed, since in their case, reasons for not working were more related to difficulty in finding jobs. However, age differences were not as significant for this sample as emphasized in the literature (Maslove et al., 1998).

Graduates' earnings and income differences by program of study, gender and age were the most discussed labour market outcomes (Allen et al., 2003; Finnie, 2001; Giles, 2002; Heisz, 2003; Maslove et al., 1998; Walters, 2004) obtained using either cross-sectional or longitudinal samples of NGS surveys. For the BC Class of ' 96 , study findings showed a quite promising overall increase of 23\% in median earnings in 2001 as compared to 1997; yet, income levels indicated large discrepancies by type of program, gender and somehow age at both survey times.

There was a consistent difference in earnings between the liberal arts and graduates from applied programs in our study. The salary gap decreased from 1997 to 2001, but only from 19\% to 16\%, which suggests that with this rate of 
change, it would take another 15 years to reach equal levels. Similarly, Heisz (2003) looks at the earnings' distribution of BC university graduates from the cohorts of 1974 through 1996 and identifies the applied degrees of engineering, medical sciences, and commerce at the top of median earnings, and liberal arts degrees like fine arts and humanities at the bottom of the distribution. However, Heisz concluded that predicted median earnings by field of study tend to equalize eventually. He also notices that most graduates do not earn the average earnings associated with their field of study and recommends comparing the distribution of earnings instead of median values. The TUPC sample used in our study contains a number of liberal arts graduates who earned much more than the median earning of the group, but still they represent exceptions. Median earnings give a good indication of the amount earned by each group, and differences by type of program were still significantly large five years after graduation.

It is reasonable to expect that different university programs result in differences in future earnings. University programs provide different skills and competences to students that may respond more or less effectively to employers' needs (Brown, 2001a, 2001b; Davenport, 2002; Lin, Sweet \& Anisef, 2003). Many applied programs are longer than liberal arts programs and this may lead to the assumption that "more education" deserves better financial reward. As pointed out by Walters (2004), differences in labour market outcomes are possibly related to a selection effect and a "gate-keeping" mechanism that allows some university programs to "raise the average wage and employment levels of their graduates simply by keeping their enrolment numbers low" (p.21). Discrepancy in labour market outcomes by field of study could be determined by various educational, social, political and economic factors, and this issue requires a complex analysis which is beyond the scope of this paper. Rather than making judgements regarding the economic returns on education in absolute terms for various fields of study, we used the available longitudinal data to present patterns of change in labour market outcomes.

Gender differences show consistently that men are better paid than women in similar employment situations. One year after graduation, differences as large as $14 \%$ were observed for the graduates from applied program age 24 or less. In 2001, the salary gap was even larger, reaching up to 33\% differences for the same group. Not only did male salaries started at higher levels, but they experienced a larger rate of growth that, as Finnie (2001) also noted, expanded the gender salary gap.

As shown by Allen et al. (2003) the labour market climate has changed dramatically during the last two decades and this has had a large impact on unemployment rates of young adults and consequently on earnings. Their findings emphasized that the younger graduates, less than 25 years old, experienced the largest labour market transition difficulties. Maslove et al. (1998) also point out that younger graduates have to compete for jobs with older cohorts who have both credentials and work experience. Our findings 
demonstrate that age differences in earnings were visible in 1997, showing that older graduates have an advantage in finding more stable work and receiving higher incomes. These differences become less significant over time. In 2001, the higher income earned by males under the age of 25 as compared to their older colleagues in both liberal arts and applied programs, suggests that the labour market competition between young and older university graduates is not necessarily unfair as pointed by Maslove et al.

Our study findings show that graduates from applied program, who were more successful in obtaining higher labour market outcomes, had also been more job-oriented in setting these specific educational goals. By contrast, the liberal arts graduates showed a different pattern of goal setting. One year after graduation, their level of satisfaction with goals attainment was lower than for applied programs graduates, either because graduates were still negotiating their career opportunities or because their educational goals have not yet been attained in 1997.

\section{CONCLUSION}

The aim of this paper was to look solely at the economic integration of graduates in the labour market and the optimal capitalization of their university education. Graduates from liberal arts and applied programs are expected to confront the reality of a labour market where the measure of success consists in securing a stable job and attaining career satisfaction. In regard to preparing graduates for realities of the labour market, the university is less successful in the case of liberal arts graduates, who experience delayed integration and professional recognition. In contrast, labour market outcomes like employment status and income point toward a net advantage of being a graduate of an applied program. Over time, differences in labour market outcomes between liberal arts graduates and graduates from applied programs appear to diminish, since liberal arts graduates find more pragmatic ways to capitalize on their education. There is a need for more longitudinal research in order to understand how this happens and how competences developed through a liberal arts tradition are transformed into success in the labour market. Additional research will also shed more light on the aspirations and dispositions of those who choose to embark on a liberal arts or an applied program.

The study findings show that students arrive on university campuses with a variety of goals, expecting that university education will shape their knowledge, skills, and overall formation that will permit them to bring their aspirations to reality. This reality represents not only intellectual excitement, social interaction or community ideals; it also represents a labour market where success means securing a good job. On the whole, the labour market outcomes for applied and liberal graduates are satisfactory, which indicates that university education gets recognition and reward in the labour market. This information will be useful for educational planning and program choice by individual students as well as by the university in increasing the effectiveness of career counseling 
centres. In recognizing that preparing graduates for employment is one of the aims of university education, examining the fit between education achievement and labour force participation encourages the university to examine and make explicit the role of labour force preparation and outcomes in university curricula.

One aim of this paper was to point out that labour market outcomes are just one dimension that describes how human capital accumulated through university education translates into good employment in a knowledge-based economy. We argue that individuals measure their professional attainment not only in economic terms, but also in setting and attaining educational and career goals, in developing and growing interest for a field of study, in achieving personal growth and enhancing social interaction. These more subjective measures are not only essential for a better understanding of the individual perspective on the return to education; they should become more thoroughly analyzed from an institutional and societal perspective as well, in order to develop adequate practice and policy for academic programs and university services.

\section{NOTES}

1 The 1997 survey was conducted 18 months after graduation, but will be referred to as the one year follow-up survey.

2 Based on the CIP coding scheme, program areas like Fine Arts, Humanities, Social Sciences, Life and Physical Sciences fit under the liberal arts category (i.e., general instruction curriculum), as compared to the other program areas that are applied (i.e., skill formation). However, there is no perfect mapping between the CIP coding scheme and a definition of liberal arts and applied programs based on the specificity of the academic curriculum (Lin et al., 2000). As a result, some programs from the Humanities, Social Sciences or Life Sciences fit in the liberal arts category (e.g., English, Geography, Biology) while others fit in the applied programs category (e.g., Applied Linguistics, Social Work, Dietetics).

3 Information on employment status and earnings was covered in detail at both survey times. Data on occupations, work sector (public/private), and other details that could have provided additional insight into graduates' labour market outcomes, were either not available or less reliable.

4 The term "further education" was used in the TUPC questionnaires and describes any form of education or training carried out by respondents after graduation. It has a broader meaning than "further studies," the term used by Finnie (2001) to refer only to those who completed a new diploma after graduation.

5 We selected the term "school" for its conventional meaning of formal structured learning. 


\section{REFERENCES}

Adamuti-Trache, M. \& Sweet, R. (2005). Exploring the relationship between educational credentials and the earnings of immigrants. Canadian Studies in Population, 32(2), 177-201.

Allen, M., Harris, S., \& Butlin, G. (2003). Finding their way: A profile of young Canadian graduates. Catalogue no. 81-595-MIE, Ottawa: Ministry of Industry \& Statistics Canada.

Andres, L., \& Carpenter, S. (1998). Today's higher education students: Issues of admission, retention, transfer and attrition in relation to changing student demographics. Research report for the British Columbia Council on Admissions and Transfer.

Axelrod, P., Anisef, P., \& Lin, Z. (2001). Against all odds? The enduring value of liberal education in universities, professions and the labour market. The Canadian Journal of Higher Education, 31(2), 47-78.

Axelrod, P. (2002). Values in conflict. The university, the marketplace, and the trials of liberal education. Montreal: McGill-Queen's University Press.

Brown, P., Hesketh, A., \& Williams, S. (2003). Employability in a knowledgedriven economy. Journal of Education and Work, 16(2), 107-126.

Brown, P. (2001a). Skill formation in the twenty-first century. In P. Brown, A. Green, \& H. Lauder (Eds.), High skills - Globalization, competitiveness, and skill formation (pp. 1 - 55). Oxford: Oxford University Press.

Brown, P. (2001b). Globalization and the political economy. In P. Brown, A. Green, \& H. Lauder(Eds.), High skills - Globalization, competitiveness, and skill formation (pp. 235 - 262). 0xford: Oxford University Press.

Davenport, P. (2002). Universities and the knowledge society. In D. Laidler (Ed). Renovating the ivory tower: Canadian universities and the knowledge economy, (pp. 39-59). Toronto: C. D. Howe Institute.

Easton, S. (2002). Do we have a problem? Women and men in higher education. In D. Laidler (Ed). Renovating the ivory tower: Canadian universities and the knowledge economy, (pp. 60-79). Toronto: C. D. Howe Institute.

Finnie, R. (2001). Fields of plenty, fields of lean: The early labour market outcomes of Canadian university graduates by discipline. The Canadian Journal of Higher Education, 31(1), 41-176.

Giles, P. (2002). Liberal arts degrees and the labour market. Education Quarterly Review, 8(2), 19-25. 
Graham, G. (2002). Universities: The recovery of an idea. Charlottesville: Imprint Academic.

Hawkey, C., \& Lee, R. (1999). Class of '96. One-year after graduation. Retrieved July 30, 2005, from The University Presidents' Council of British Columbia Website: http://www.tupc.bc.ca/student_outcomes/ publications/ graduate_outcomes/

Heijke, H., \& Muysken, J. (Eds.) (2000). Education and training in a knowledge-based economy. London: MacMillan Press. Ltd.

Heisz, A. (2003). Relative earnings of British Columbia university graduates. Education Quarterly Review, 9(1), 35-47. Ottawa: Statistics Canada.

Lavoie, M., \& Roy, R. (1998). Employment in the knowledge-based economy: A growth accounting exercise for Canada. (R-98-8E) Ottawa: Human Resources Development Canada.

Lin, Z., Sweet, R., Anisef, P., \& Schuetze, H. G. (2000). The National Graduate Surveys - Consequences and policy implications for university students who have chosen liberal or vocational education. Ottawa: Human Resources Development Canada.

Lin, Z., Sweet, R., \& Anisef, P. (2003). Consequences and policy implications for university students who have chosen liberal or vocational education in Canada: labour market outcomes and employability skills. Higher Education Policy, 16, 55-85.

Maslove, L., Fischer, L., \& O'Heron, H. (1998). Making the transition: No two paths alike. Research File, 2(4), 1-11.

Ministère de l'Éducation Quebec (2003). Relance survey of university graduates - 2003. Employment situation of graduates, 2001 and 2003 surveys. (code: 20-5003-01a) Retrieved July 30, 2005, from http://www.mels.gouv.qc.ca/ Relance/Universite/RelUni03/RelUni03.htm

Pitcher, J., \& Purcell, K. (1998). Diverse expectations and access to opportunities: Is there $a$ graduate labour market? Higher Education Quarterly, 52(2), 179-203.

Rubenson, K., \& Schuetze, H. G. (2000). Lifelong learning for the knowledge society: Demand, supply, and policy dilemmas. In K. Rubenson \& H. G. Schuetze (Eds.), Transition to the knowledge society: Policies and strategies for individual participation and learning, (pp. 355- 376). Vancouver: UBC (Institute for European Studies). 
Schuetze, H. G. (2000). Higher education and lifelong learning in Canada: Re-interpreting the notions of 'traditional' and 'non-traditional students' in a 'knowledge society'. In H. G. Schuetze \& M. Slowey (Eds.), Higher education and lifelong learners: International perspectives on change (pp. 127 - 144). London and New York: Routledge - Falmer.

Statistics Canada (2003a). Education in Canada: Raising the standard. 2001 Census analysis series, Catalogue no. 96F0030XIE, Ottawa: Statistics Canada.

Statistics Canada (2003b). Education indicators in Canada: Report of the Pan-Canadian Education Indicators Program 2003. Catalogue no. 81-582-XIE, Ottawa: Statistics Canada.

Sudmant, W., Greenall, J., Lambert-Maberly, A., \& Dumaresq, C. (2003). Class of '96. Five years after graduation. Retrieved July 30, 2005, from The University Presidents' Council of British Columbia Website: http://www.tupc. bc.ca/student_outcomes/publications/graduate_outcomes/

Walters, D. (2004). A comparison of the labour market outcomes of postsecondary graduates of various levels and fields over a four-cohort period. Canadian Journal of Sociology, 29(1), 1-27.

\section{ACKNOWLEDGEMENTS}

The authors wish to acknowledge the support of The University Presidents' Council of British Columbia and Mr. Walter Sudmant, Planning and Institutional Research (UBC), for providing access to the data used in this study.

\section{CONTACT INFORMATION}

Maria Adamuti-Trache

University of British Columbia, Faculty of Education

2125 Main Mall, Vancouver, B.C. V6T $1 Z 4$

maria.trache@ubc.ca

Maria Adamuti-Trache obtained a doctoral degree in statistical physics from the University of Bucharest (Romania), where she taught theoretical physics for fifteen years. She also received an MA in higher education from the University of British Columbia, and is currently completing a $\mathrm{PhD}$ in Educational Studies. Maria has expertise in life course research, which explores the impact of gender, age, social class, ethnicity and immigrant status on education and work transitions. Due to her background as a physics professor, she is particularly interested in math and science education in relation to science-related pathways. Maria is currently Research Manager with Edudata Canada, and Statistical Consultant in the Faculty of Education, UBC. 
Colleen Hawkey has a Ph.D. in Educational Studies from The University of British Columbia with a specialisation in Higher Education. She has several years of adult education teaching experience, working with disadvantaged groups in institutional and non-institutional settings. She has extensive survey research experience and experience assessing effectiveness of programs in the areas of recidivism, cognitive skills development, "intentional" communities, inter-professional education and skills training. Her current research interests focus on student success and educational outcomes and include work on student retention and attrition, quality of student life, labour force transition and employment outcomes. Colleen is Research Analyst with the British Columbia Teachers' Federation.

Hans G. Schuetze studied social sciences, economics, and law at the universities of Göttingen and Bonn (Germany), Grenoble (France) and of California at Berkeley (USA). Since 1991, he was professor of Higher Education in the Department of Educational Studies University of British Columbia and a Senior Fellow at the Centre for Policy Studies in Higher Education and Training (of which he was the Director 2002 to 2006). Professor emeritus since 2006, he has joined a law practice in Hannover, Germany, specializing in education and the law as well as international human rights issues.

Victor Glickman has an EdD in Educational Studies from the University of British Columbia. He is the founding Director of Edudata Canada an independent education and learning research centre at UBC, a Research Associate at the UBC Faculty of Education and an adjunct professor in the Faculty of Education at the University of Victoria. He is President of the Canadian Education Research Association. Victor Glickman has broad experience in leading complex large scale quantitative research projects at the community, provincial, regional, national and internationals level and providing strategic research and policy advice. These projects involve education policy and research, management consulting, post secondary education policy, strategic and policy and program development. 


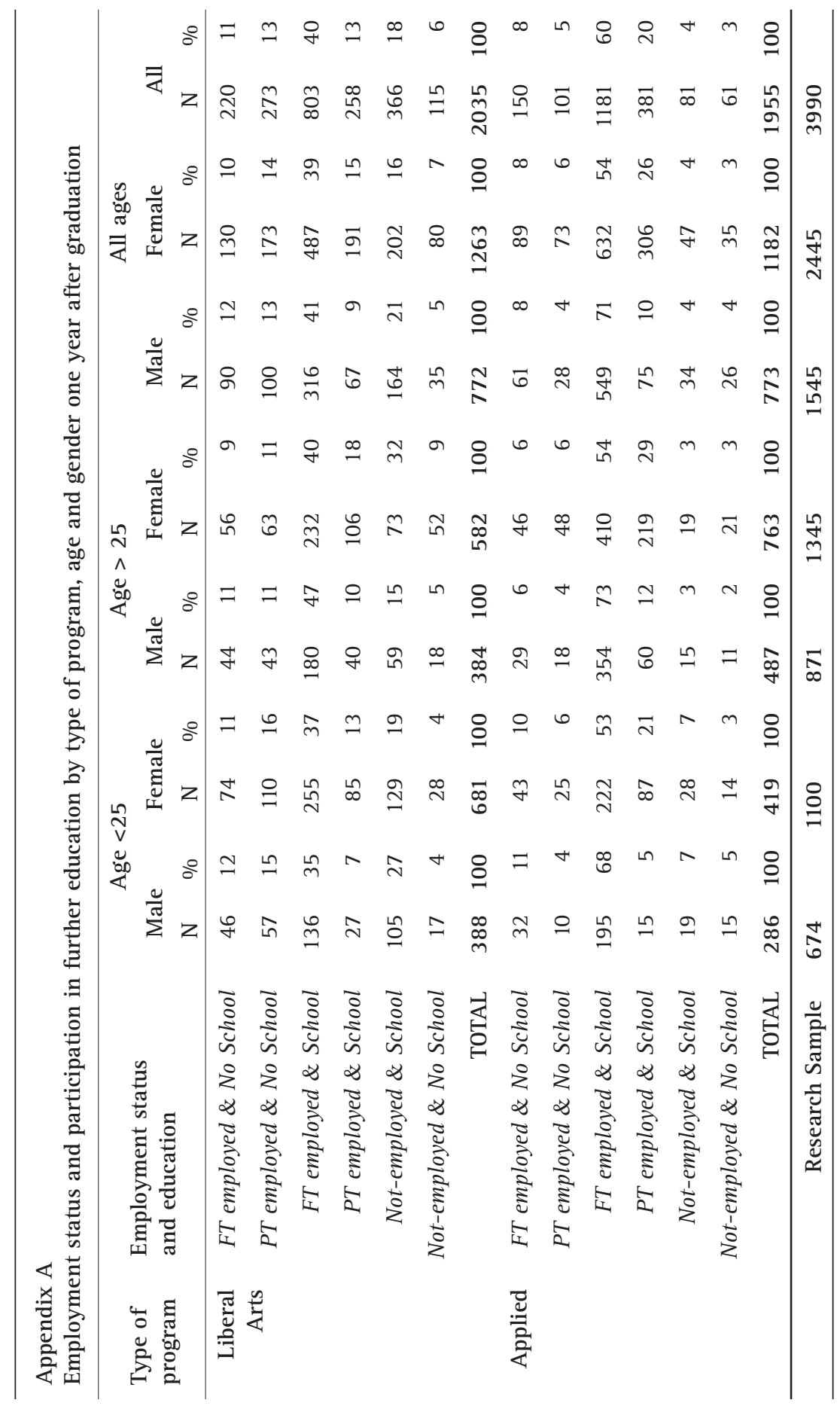




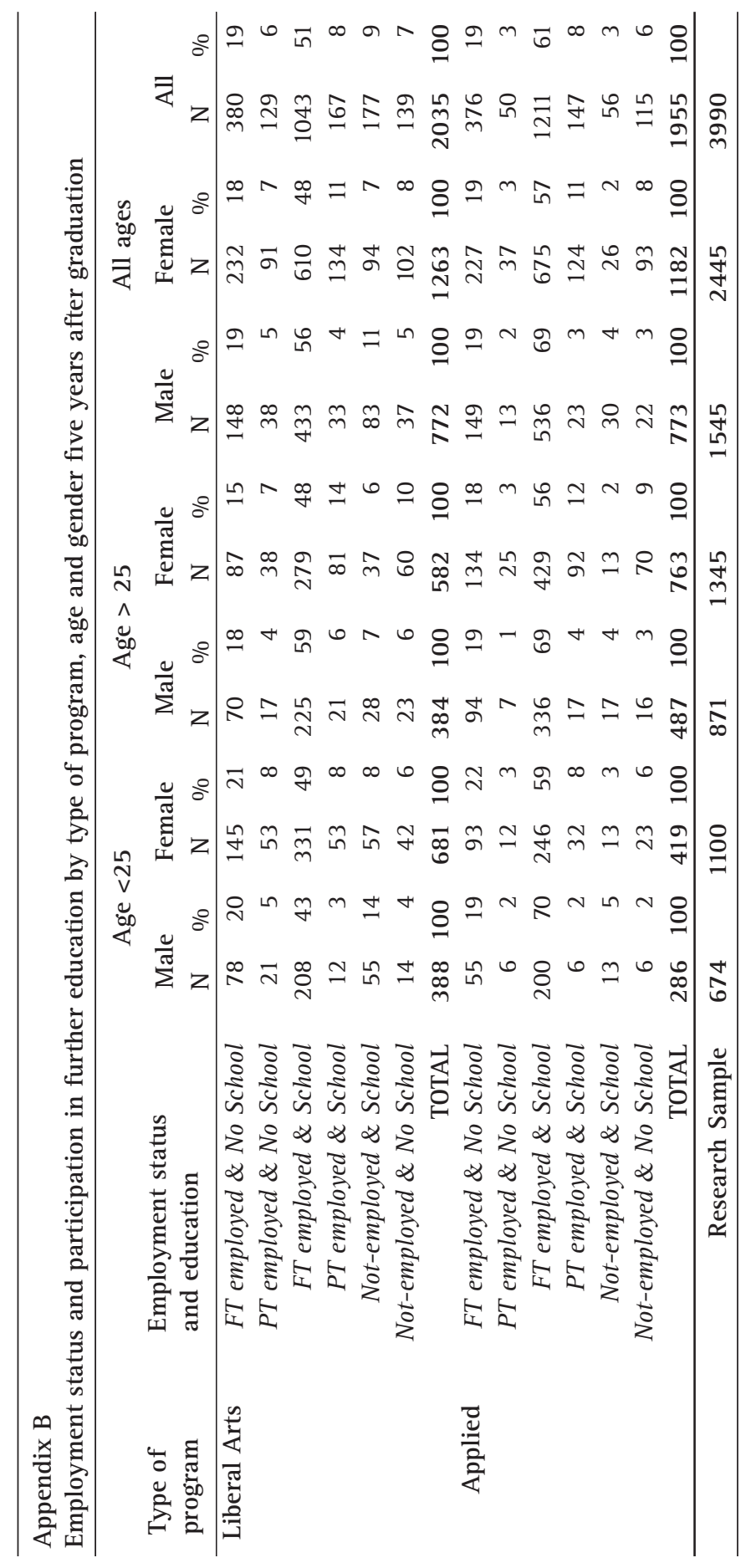


